\title{
In vitro and in vivo antioxidant activities of polyphenol extracted from black garlic
}

\author{
Weidong $\mathrm{WANG}^{1}$, Yuee SUN ${ }^{1 *}$
}

\begin{abstract}
This study investigated the in vitro and in vivo antioxidant activities of polyphenol extracted from black garlic. Black garlic polyphenol (BGP) was extracted from black garlic. The in vitro antioxidant activities of BGP were determined using DPPH., $\mathrm{OH}$ and $\mathrm{O}^{2-}$ radical scavenging assays. The in vivo antioxidant activities were determined by detecting the malondialdehyde (MDA) content and superoxide dismutase (SOD) and glutathione peroxidase (GSH-Px) activities in mice. Results showed that, the DPPH. radical inhibition rate of 200 and $250 \mu \mathrm{g} / \mathrm{mL}$ BGP was equivalent with Vc (P > 0.05). With concentration of 400 and $500 \mu \mathrm{g} / \mathrm{mL}$, the $\mathrm{OH}$ radical inhibition rate of $\mathrm{BGP}$ was slightly lower than $\mathrm{Vc}(\mathrm{P}>0.05)$. The $\mathrm{O}^{2-}$ radical inhibition rates of $200,400,600,800$ and $1000 \mu \mathrm{g} / \mathrm{mL}$ BGP were significantly lower than $\mathrm{Vc}(\mathrm{P}<0.05)$. In the groups treated with BGP with suitable dose, the serum MDA content was significantly decreased compared with model group $(\mathrm{P}<0.05)$, and the serum SOD and GSH-Px activities were significantly increased $(\mathrm{P}<0.05)$. BGP has obvious DPPH. and $\cdot \mathrm{OH}$ radical scavenging activities, and can significantly decrease the serum MDA content in mice with oxidative damage, and increase the serum SOD and GSH-Px activities.
\end{abstract}

Keywords: black garlic; polyphenol; antioxidant activity.

Practical Application: Black garlic polyphenol has certain in vitro and in vivo antioxidant activities, and is worthy of further popularization and application.

\section{Introduction}

Garlic (Allium sativum L.) is considered as one of the best health daily foods. It has anti-bacterial and anti-inflammatory activities, and can improve the body immunity, treat cardiovascular diseases and prevent cancer (Galeone et al., 2006; Rahman \& Lowe, 2006). Black garlic is a new type of garlic products, which is processed from fresh garlic by enzyme treatment, curing and drying. Black garlic has the sweet and sour taste and good mouth feel, without garlic pungent, and can be eaten directly. Compared with fresh garlic, the black garlic has richer nutrition and enhanced biological activity, and the application prospect is more extensive (Jung et al., 2014). It is found that, the total phenolic content in black garlic is 5-8 time higher than that of fresh garlic, so the black garlic has higher antioxidant activity than fresh garlic (Kim et al., 2013a). Phenolic compounds are the important functional components in black garlic, and are the important indicator to measure the quality of fresh garlic product (Choi et al., 2014). Therefore, it is of great significance to study the phenolic compounds in black garlic. In this study, the black garlic polyphenol (BGP) was extracted from the black garlic, in vivo and in vitro antioxidant activities of BGP were investigated. The objective was to provide a basis for further studying the active components of BGP and their applications.

\section{Materials and methods}

\subsection{Materials}

Black garlic was prepared in our laboratory. It was fermented from fresh garlic in constant temperature and humidity box $\left(75^{\circ} \mathrm{C}\right.$, $85 \%$ relative humidity) for 12 consecutive days. Clean-grade male Kunming mice (weight $20.0 \pm 1.8 \mathrm{~g}$, fed in standard animal house, with basic pellet feed, free eating and drinking water) were provided by Laboratory Animal Center, Nanjing Medical University. Malondialdehyde (MDA), superoxide dismutase (SOD) and glutathione peroxidase (GSH-Px) were purchased from Nanjing Jiancheng Biological Engineering Institute (Nanjing, China). Gallic acid standard was provided by National Institutes for Food and Drug Control (Beijing, China). Folin phenol reagent, 2.2-diphenyl-1-picrylhydrazinyl (DPPH), vitamin $\mathrm{C}(\mathrm{Vc})$ and other regents were provided by Sigma-Aldrich Corp. (MO, USA).

\subsection{Extraction of BGP}

Black garlic was washed, and was dried at $50{ }^{\circ} \mathrm{C}$ in oven, followed by smashing in crushing machine and sieving using 100 mesh sieves. Black garlic powder was added to $80 \%$ (V/V) ethanol solution, followed by oscillation extraction at $40^{\circ} \mathrm{C}$ water bath for $3 \mathrm{~h}$. After filtration, the residue was extracted for repeated 2 times. The filtrates of three extractions were mixed, followed by rotary evaporation with vacuum at $45^{\circ} \mathrm{C}$ to removing ethanol 
and obtaining the extractum. The extractum was dissolved in water, and then was adsorbed in AB-8 macroporous adsorption resin. After elution using 20\% (V/V) ethanol solution, the eluate was obtained and was filtered by $0.45 \mu \mathrm{m}$ microfiltration membrane. After vacuum concentration and vacuum-freeze drying, the BGP product was obtained. After determination by Folin-Ciocalteu colorimetric method, the polyphenol content in BGP product was $8.45 \%$.

\subsection{Determination of in vitro antioxidant activities of BGP}

In vitro antioxidant activity experiments included DPPH. radical scavenging assay, $\mathrm{OH}$ radical scavenging assay and $\mathrm{O}^{2-}$ radical scavenging assay. The $\mathrm{DPPH} \cdot$ radical scavenging assay was performed based on the method reported by Zhang et al. (2011) with some modifications; the $\mathrm{OH}$ radical scavenging assay was performed according to the method reported by Su et al. (2009); the $\mathrm{O}^{2-}$ radical scavenging assay was performed according to the method reported by Liu et al. (1997). All experiments were repeated for three times.

\subsection{Determination of in vivo antioxidant activities of $B G P$}

Fifty Kunming mice were randomly divided into 5 groups including control group, model group, 10, 20 and $40 \mathrm{mg} / \mathrm{kg}$ BGP group, 10 mice in each group. The control group and model group were intragastrically administered with $0.2 \mathrm{~mL}$ distilled water, and other 3 groups were intragastrically administered with BGP at dose of 10,20 and $40 \mathrm{mg} / \mathrm{kg}$, respectively. The administration was performed once per day. After 20 days, the mice were starved overnight (fasting for $12 \mathrm{~h}$ ), and the model group, 10, 20 and $40 \mathrm{mg} / \mathrm{kg}$ BGP group were intragastrically administered with benzene bromide dissolved in olive oil $(0.4 \mathrm{mg} / \mathrm{kg})$ at dose of $0.2 \mathrm{~mL} / 20 \mathrm{~g}$. The control group was given the same volume of olive oil. After $20 \mathrm{~h}$, the blood was gained from the eyeballs of mice, and the serum was isolated. The serum MDA content was determined according to the method reported by Placer et al. (1966), the serum SOD activity was determined according to the method reported by Minami \& Yoshikawa (1979), and the serum GSH-Px activity was determined according to the method reported by Paglia \& Valentine (1967). The test was repeated for three times.

\subsection{Statistical analysis}

All statistical analysis was carried out using SPSS13.0 software (SPSS Inc., Chicago, IL, USA). The data were presented as mean \pm SD. Comparison between two groups was performed using $t$ test. $P<0.05$ was considered as statistically significant.

\section{Results}

\subsection{DPPH radical scavenging activity of BGP}

DPPH radical inhibition rate of BGP with concentration of 50, 100 and $150 \mu \mathrm{g} / \mathrm{mL}$ was significantly lower than that of $\mathrm{Vc}$ with the same concentration $(\mathrm{P}<0.05)$. When the concentration was 200 and $250 \mu \mathrm{g} / \mathrm{mL}$, the DPPH. radical inhibition rate of BGP was equivalent with that of $\mathrm{Vc}$ with the same concentration, with no significant difference between them $(P>0.05)$.
The $\mathrm{IC}_{50}$ values of BGP and Vc for DPPH. radical inhibition were 140.79 and $80.45 \mu \mathrm{g} / \mathrm{mL}$, respectively (Figure 1).

\section{2 $\mathrm{OH}$ radical scavenging activity of BGP}

Figure 2 showed taht, the $\mathrm{OH}$ radical inhibition rate of $\mathrm{BGP}$ with concentration of 100,200 and $200 \mu \mathrm{g} / \mathrm{mL}$ was significantly lower than that of $\mathrm{Vc}$ with the same concentration $(\mathrm{P}<0.05)$. When the concentration was 400 and $500 \mu \mathrm{g} / \mathrm{mL}$, the $\mathrm{OH}$ radical inhibition rate of BGP was slightly lower than that of Vc with the same concentration, and the difference was not significant $(\mathrm{P}>0.05)$. The $\mathrm{IC}_{50}$ values of $\mathrm{BGP}$ and $\mathrm{Vc}$ for $\cdot \mathrm{OH}$ radical inhibition were $268.09 \mu \mathrm{g} / \mathrm{mL}$ and $215.98 \mu \mathrm{g} / \mathrm{mL}$, respectively.

\section{3 $\mathrm{O}^{2-}$ radical scavenging activity of $\mathrm{BGP}$}

As shown in Figure 3 , the $\mathrm{O}^{2-}$ radical inhibition rate of $\mathrm{BGP}$ with concentration of $200,400,600,800$ and $1000 \mu \mathrm{g} / \mathrm{mL}$ was significantly lower than that of $\mathrm{Vc}$ with the same concentration

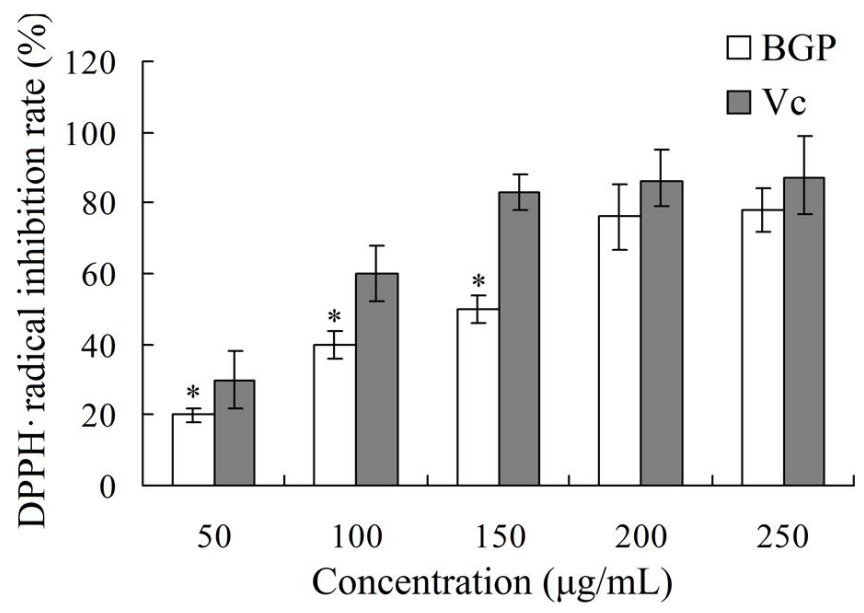

Figure 1. DPPH radical inhibition rate of BGP and Vc. BGP: black garlic polyphenols; Vc: vitamin C; DPPH: 2.2-diphenyl-1-picrylhydrazinyl. ${ }^{\star} P<0.05$ compared with $\mathrm{Vc}$.

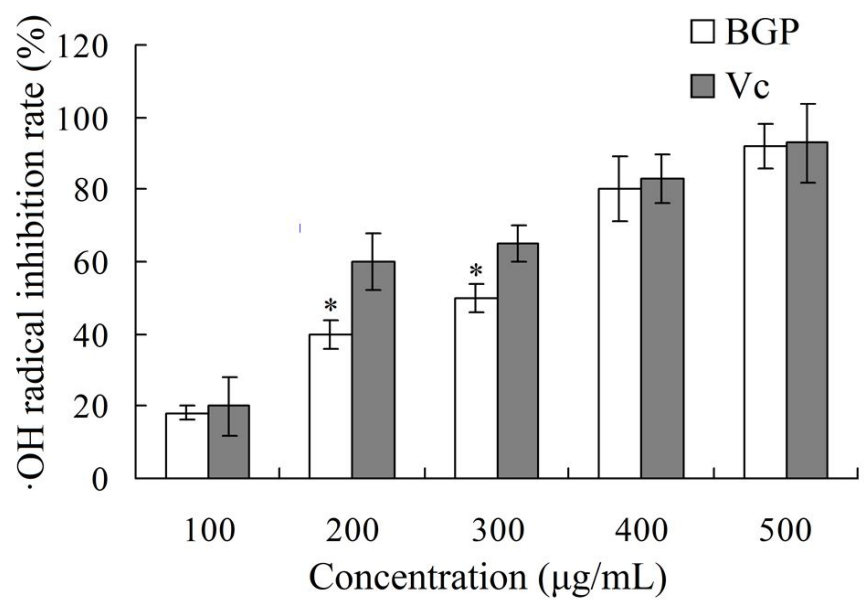

Figure 2. OH radical inhibition rate of BGP and Vc. BGP: black garlic polyphenols; Vc: vitamin C. ${ }^{\star} P<0.05$ compared with Vc. 


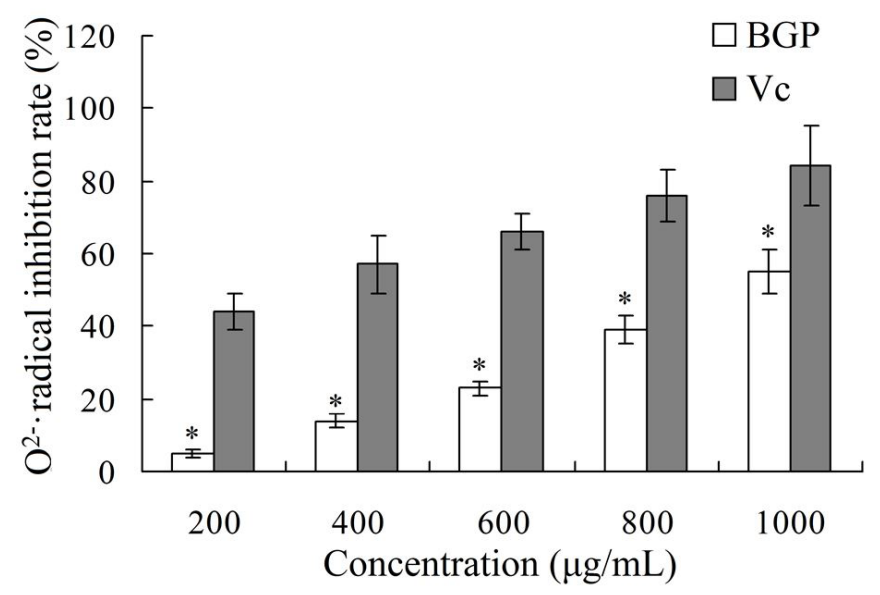

Figure 3. $\mathrm{O}^{2-}$ radical inhibition rate of BGP and Vc. BGP: black garlic polyphenols; Vc: vitamin C. ${ }^{\star} P<0.05$ compared with Vc.

$(\mathrm{P}<0.05)$. The $\mathrm{IC}_{50}$ values of $\mathrm{BGP}$ and $\mathrm{Vc}$ for $\mathrm{O}^{2-}$ radical inhibition were $964.80 \mu \mathrm{g} / \mathrm{mL}$ and $288.89 \mu \mathrm{g} / \mathrm{mL}$, respectively.

\subsection{Effect of BGP on serum MDA content in mice}

Figure 4 showed that, the serum MDA content in model group was significantly higher than control group $(\mathrm{P}<0.05)$. BGP with dose of $10 \mathrm{mg} / \mathrm{kg}$ could not significantly decrease the serum MDA content $(10 \mathrm{mg} / \mathrm{kg}$ BGP vs control, $\mathrm{P}<0.05$; $10 \mathrm{mg} / \mathrm{kg}$ BGP vs model, $\mathrm{P}>0.05)$. Compared with model group, the MDA contents in 20 and $40 \mathrm{mg} / \mathrm{kg}$ BGP groups were significantly decreased $(\mathrm{P}<0.05)$, and there was no significant difference between $20 \mathrm{mg} / \mathrm{kg}$ BGP group and control group $(\mathrm{P}>0.05)$ and between $40 \mathrm{mg} / \mathrm{kg}$ BGP group and control group $(\mathrm{P}>0.05)$, and there was no significant difference between 20 and $40 \mathrm{mg} / \mathrm{kg}$ BGP groups $(\mathrm{P}>0.05)$.

\subsection{Effect of BGP on serum SOD activity in mice}

Serum SOD activity in model group and $10 \mathrm{mg} / \mathrm{kg}$ BGP group was significantly lower than control group, respectively $(\mathrm{P}<0.05)$. The serum SOD activities in 20 and $40 \mathrm{mg} / \mathrm{kg} \mathrm{BGP}$ groups were significantly higher than model group, respectively $(\mathrm{P}<0.05)$. There was no significant difference between each two of $20 \mathrm{mg} / \mathrm{kg}$ BGP, $40 \mathrm{mg} / \mathrm{kg}$ BGP and control groups $(\mathrm{P}>0.05)$ (Figure 5).

\subsection{Effect of BGP on serum GSH-Px activity in mice}

Serum GSH-Px activity in model group was significantly lower than control group $(\mathrm{P}<0.05)$, and that in 10 and $20 \mathrm{mg} / \mathrm{kg}$ BGP groups was also significantly lower than control group, respectively $(\mathrm{P}<0.05)$. The serum SOD activity in $40 \mathrm{mg} / \mathrm{kg}$ BGP groups was significantly higher than model group, respectively $(\mathrm{P}<0.05)$. There was no significant difference among model, $10 \mathrm{mg} / \mathrm{kg}$ BGP and $20 \mathrm{mg} / \mathrm{kg}$ BGP groups $(\mathrm{P}>0.05)$ (Figure 6).

\section{Discussion}

Modern science researches believe that, the human aging and the aging related diseases are related to the imbalance between the production of highly-reactive free radicals in body and the

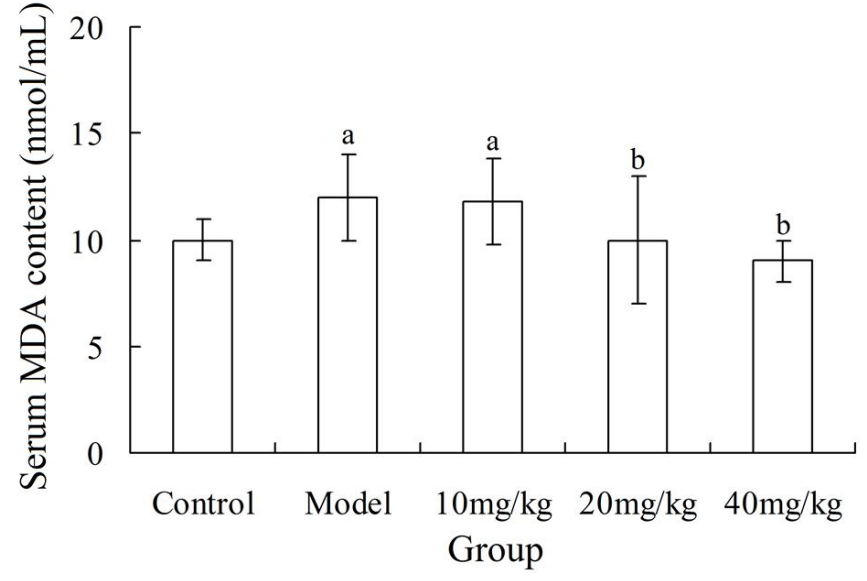

Figure 4. Effect of BGP on serum MDA content in mice. BGP: black garlic polyphenols; a: $P<0.05$ compared with control group; $\mathrm{b}: P<0.05$ compared with mode group. MDA: malondialdehyde.

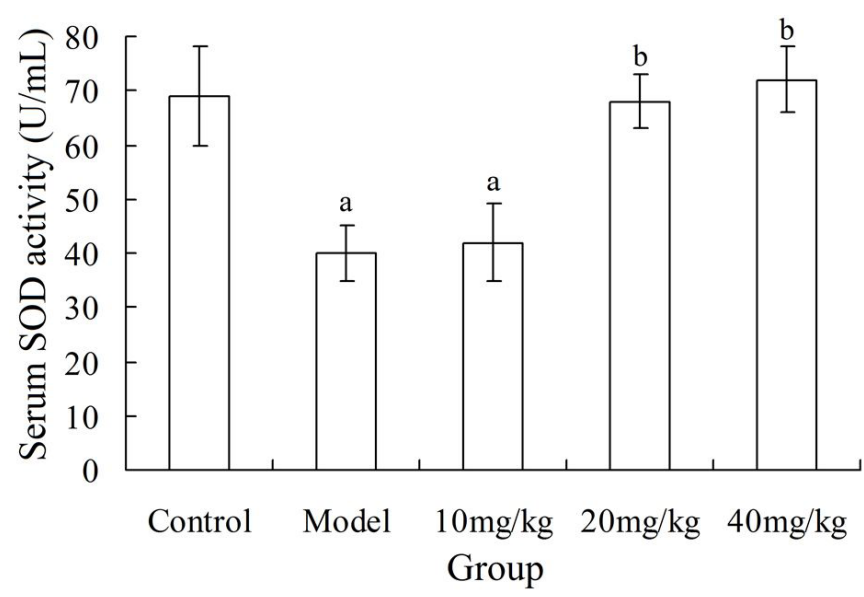

Figure 5. Effect of BGP on serum SOD activity in mice. a: $P<0.05$ compared with control group; $\mathrm{b}: P<0.05$ compared with mode group. BGP: black garlic polyphenols; SOD: superoxide dismutase.

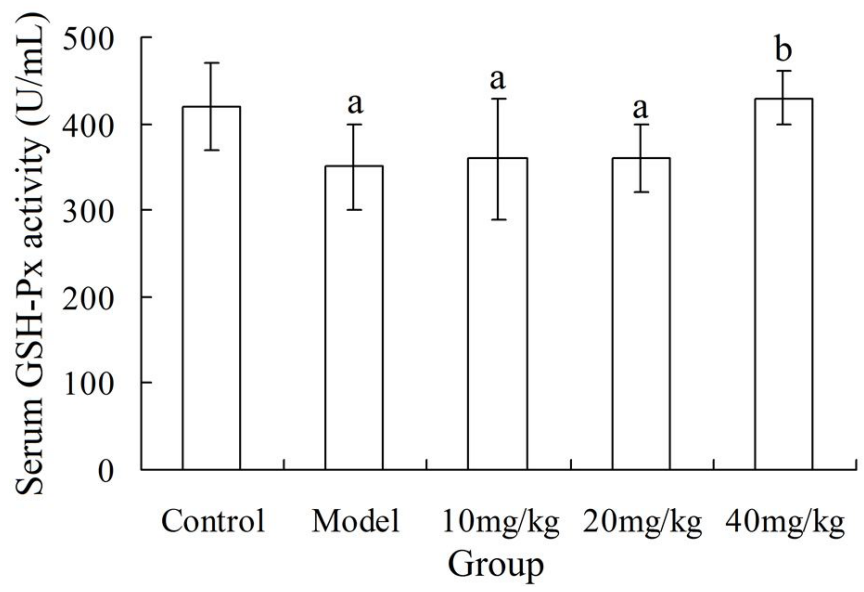

Figure 6. Effect of BGP on serum GSH-Px activity in mice. a: $P<0.05$ compared with control group; b: $P<0.05$ compared with mode group. BGP: black garlic polyphenols; GSH-Px: glutathione peroxidase. 
scavenging of radicals by antioxidant enzymes (Pierrefiche \& Laborit, 1995). This imbalance can cause the excessive concentration of free radicals in body, leading to the oxidative damage of cell membranes, lipids, nucleic acids and proteins, which results in the cell structure and function destruction and occurrence and development of diseases (Blokhina et al., 2003). Garlic has the antibacterial (Farbman et al., 1993), antiviral (Tsai et al., 1985), anti-inflammatory (Kim et al., 2013b), insecticidal (Yang et al., 2009), blood lipid regulating (Bordia et al., 1998), blood glucose decreasing (Bordia et al., 1998), detoxification (Sheen et al., 1996), atherosclerosis preventing (Bordia et al., 1977) and immunity improving (Qiu et al., 2014) functions. It is reported that, the pharmacological effects of garlic are closely related to its antioxidant properties (El-Din et al., 2014). Black garlic is derivative of garlic after fermentation preparation. It can preserve partial nutrients of garlic. After fermentation, the content of polyphenol in black garlic is much higher than ordinary garlic (Su et al., 2009). Therefore, the antioxidant activities of black garlic is worth of attention. In this study, BGP was extracted from the black garlic. After determination by Folin-Ciocalteu colorimetric method, the content of polyphenol in BGP product was $8.45 \%$. This indicates that, black garlic has relatively higher content of polyphenol, which has provided a basis for its antioxidant activities.

In vitro antioxidant activity test is often used to evaluate the potential antioxidant activity of some substances, and was used as a basis for in vivo antioxidant test. The scavenging ability assays on $\mathrm{DPPH}$ - radical, $\cdot \mathrm{OH}$ radical and $\mathrm{O}^{2-}$. radical were the common used method to determine the in vitro antioxidant activities. Results of this study showed that, the DPPH. radical and -OH radical scavenging activities of BGP with low concentration were significantly lower than $\mathrm{Vc}$ with the same concentration $(\mathrm{P}<0.05)$, but those of BGP with high concentration was equivalent with $\mathrm{Vc}$ with the same concentration. This indicates that, relatively high concentration of BGP has obvious DPPH. radical and $\cdot \mathrm{OH}$ radical scavenging abilities. $\mathrm{O}^{2-} \cdot$ radical scavenging assay showed that, the $\mathrm{O}^{2-}$ radical inhibition rate of BGP with different concentrations was significantly lower than Vc with the same concentration $(\mathrm{P}<0.05)$. This indicates that, $\mathrm{BGP}$ has poor scavenging ability of $\mathrm{O}^{2-}$ radical.

MDA is one of the final products of cell membrane lipid peroxidation, which can indirectly reflect the degree of cell membrane peroxidation (Janero, 1990). SOD is an important antioxidant enzyme in the body, which can catalyze the transformation of oxygen free radicals to hydrogen peroxide, and avoid the damage to cells (Fehér et al., 1988). GSH-Px is a kind of antioxidant enzyme which can scavenge the free radicals and inhibit the free radical reaction (Pilarczyk et al., 2012). The results of this study showed that, the serum MDA content in model group was significantly higher than control group $(\mathrm{P}<0.05)$, and the serum SOD and GSH-Px activities in model group were significantly lower than control group $(\mathrm{P}<0.05)$. This indicated that, the in vivo oxidative damage model was successfully established. In the groups treated with BGP with suitable dose, the serum MDA content was significantly decreased compared with model group $(\mathrm{P}<0.05)$, and the serum SOD and GSH-Px activities were significantly increased $(\mathrm{P}<0.05)$. This indicates that, the
BGP has good in vivo antioxidant activities, which are basically in accordance with the in vitro antioxidant activities.

\section{Conclusion}

Black garlic has high content of polyphenol. BGP has obvious $\mathrm{DPPH} \cdot$ radical and $\cdot \mathrm{OH}$ radical scavenging activities, and can significantly decrease the serum MDA content in mice, and increase the serum SOD and GSH-Px activities. It is worth of further popularization and application

\section{Acknowledgements}

This work was supported by the National Natural Science Foundation of China (No. 31301535) and the Qing Lan Project of Jiangsu Province.

\section{References}

Blokhina, O., Virolainen, E., \& Fagerstedt, K. V. (2003). Antioxidants, oxidative damage and oxygen deprivation stress: a review. Annals of Botany, 91(2), 179-194. PMid:12509339. http://dx.doi.org/10.1093/ aob/mcf118.

Bordia, A., Verma, S. K., \& Srivastava, K. C. (1998). Effect of garlic (Allium sativum) on blood lipids, blood sugar, fibrinogen and fibrinolytic activity in patients with coronary artery disease. Prostaglandins, Leukotrienes, and Essential Fatty Acids, 58(4), 257-263. PMid:9654398. http://dx.doi.org/10.1016/S0952-3278(98)90034-5.

Bordia, A., Verma, S. K., Vyas, A. K., Khabya, B. L., Rathore, A. S., Bhu, N., \& Bedi, H. K. (1977). Effect of essential oil of onion and garlic on experimental atherosclerosis in rabbits. Atherosclerosis, 26(3), 379386. PMid:192252. http://dx.doi.org/10.1016/0021-9150(77)90092-2.

Choi, I. S., Cha, H. S., \& Lee, Y. S. (2014). Physicochemical and antioxidant properties of black garlic. Molecules (Basel, Switzerland), 19(10), 16811-16823. PMid:25335109. http://dx.doi.org/10.3390/ molecules191016811.

El-Din, S. H., Sabra, A. N., Hammam, O. A., Ebeid, F. A., \& El-Lakkany, N. M. (2014). Pharmacological and antioxidant actions of garlic and.or onion in non-alcoholic fatty liver disease (NAFLD) in rats. Journal of the Egyptian Society of Parasitology, 44(2), 295-308. PMid:25597144. http://dx.doi.org/10.12816/0006468.

Farbman, K. S., Barnett, E. D., Bolduc, G. R., \& Klein, J. O. (1993). Antibacterial activity of garlic and onions: a historical perspective. The Pediatric Infectious Disease Journal, 12(7), 613-614. PMid:8346006. http://dx.doi.org/10.1097/00006454-199307000-00013.

Fehér, J., Láng, I., Nékám, K., Müzes, G., \& Deák, G. (1988). Effect of free radical scavengers on superoxide dismutase (SOD) enzyme in patients with alcoholic cirrhosis. Acta Medica Hungarica, 45(3-4), 265-276. PMid:3249654.

Galeone, C., Pelucchi, C., Levi, F., Negri, E., Franceschi, S., Talamini, R., Giacosa, A., \& La Vecchia, C. (2006). Onion and garlic use and human cancer. The American Journal of Clinical Nutrition, 84(5), 1027-1032. PMid:17093154.

Janero, D. R. (1990). Malondialdehyde and thiobarbituric acid-reactivity as diagnostic indices of lipid peroxidation and peroxidative tissue injury. Free Radical Biology \& Medicine, 9(6), 515-540. PMid:2079232. http://dx.doi.org/10.1016/0891-5849(90)90131-2.

Jung, E. S., Park, S. H., Choi, E. K., Ryu, B. H., Park, B. H., Kim, D. S., Kim, Y. G., \& Chae, S. W. (2014). Reduction of blood lipid parameters by a 12 -wk supplementation of aged black garlic: a randomized controlled trial. Nutrition (Burbank, Los Angeles County, Calif.), 
30(9), 1034-1039. PMid:24976429. http://dx.doi.org/10.1016/j. nut.2014.02.014.

Kim, J. S., Kang, O. J., \& Gweon, O. C. (2013a). Comparison of phenolic acids and flavonoids in black garlic at different thermal processing step. Journal of Functional Foods, 5(1), 80-86. http:// dx.doi.org/10.1016/j.jff.2012.08.006.

Kim, S. R., Jung, Y. R., An, H. J., Kim, D. H., Jang, E. J., Choi, Y. J., Moon, K. M., Park, M. H., Park, C. H., Chung, K. W., Bae, H. R., Choi, Y. W., Kim, N. D., \& Chung, H. Y. (2013b). Anti-wrinkle and anti-inflammatory effects of active garlic components and the inhibition of MMPs via NF- $\kappa B$ signaling. PLoS One, 8(9), e73877. PMid:24066081. http://dx.doi.org/10.1371/journal.pone.0073877.

Liu, F., Ooi, V. E., \& Chang, S. T. (1997). Free radical scavenging activities of mushroom polysaccharide extracts. Life Sciences, 60(10), 763-771. PMid:9064481. http://dx.doi.org/10.1016/S0024-3205(97)00004-0.

Minami, M., \& Yoshikawa, H. (1979). A simplified assay method of superoxide dismutase activity for clinical use. Clinica Chimica Acta, 92(3), 337-342. PMid:436274. http://dx.doi.org/10.1016/00098981(79)90211-0.

Paglia, D. E., \& Valentine, W. N. (1967). Studies on the quantitative and qualitative characterization of erythrocyte glutathione peroxidase. The Journal of Laboratory and Clinical Medicine, 70(1), 158-169. PMid:6066618.

Pierrefiche, G., \& Laborit, H. (1995). Oxygen free radicals, melatonin, and aging. Experimental Gerontology, 30(3-4), 213-227. PMid:7556504. http://dx.doi.org/10.1016/0531-5565(94)00036-3.

Pilarczyk, B., Jankowiak, D., Tomza-Marciniak, A., Pilarczyk, R., Sablik, P., Drozd, R., Tylkowska, A., \& Skólmowska, M. (2012). Selenium concentration and glutathione peroxidase (GSH-Px) activity in serum of cows at different stages of lactation. Biological Trace Element Research, 147(1-3), 91-96. PMid:22089971. http://dx.doi. org/10.1007/s12011-011-9271-y.

Placer, Z. A., Cushman, L. L., \& Johnson, B. C. (1966). Estimation of product of lipid peroxidation (malonyl dialdehyde) in biochemical systems. Analytical Biochemistry, 16(2), 359-364. PMid:6007581. http://dx.doi.org/10.1016/0003-2697(66)90167-9.

Qiu, S., Chen, J., Qin, T., Hu, Y., Wang, D., Fan, Q., Zhang, C., Chen, X., Chen, X., Liu, C., Gao, Z., \& Li, X. (2014). Effects of selenylation modification on immune-enhancing activity of garlic polysaccharide. PLoS One, 9(1), e86377. PMid:24497946. http://dx.doi.org/10.1371/ journal.pone.0086377.

Rahman, K., \& Lowe, G. M. (2006). Garlic and cardiovascular disease: a critical review. The Journal of Nutrition, 136(3, Suppl), 736S-740S. PMid:16484553.

Sheen, L. Y., Lii, C. K., Sheu, S. F., Meng, R. H., \& Tsai, S. J. (1996). Effect of the active principle of garlic-diallyl sulfide-on cell viability, detoxification capability and the antioxidation system of primary rat hepatocytes. Food and Chemical Toxicology, 34(10), 971-978. PMid:9012772. http://dx.doi.org/10.1016/S0278-6915(96)00066-X.

Su, X. Y., Wang, Z. Y., \& Liu, J. R. (2009). In vitro and in vivo antioxidant activity of Pinus koraiensis seed extract containing phenolic compounds. Food Chemistry, 117(4), 681-686. http://dx.doi. org/10.1016/j.foodchem.2009.04.076.

Tsai, Y., Cole, L. L., Davis, L. E., Lockwood, S. J., Simmons, V., \& Wild, G. C. (1985). Antiviral properties of garlic: in vitro effects on influenza B, herpes simplex and coxsackie viruses. Planta Medica, 51(5), 460461. http://dx.doi.org/10.1055/s-2007-969553.

Yang, F. L., Li, X. G., Zhu, F., \& Lei, C. L. (2009). Structural characterization of nanoparticles loaded with garlic essential oil and their insecticidal activity against Tribolium castaneum (Herbst) (Coleoptera: Tenebrionidae). Journal of Agricultural and Food Chemistry, 57(21), 10156-10162. PMid:19835357. http://dx.doi.org/10.1021/jf9023118.

Zhang, Y. W., Zhang, H., Wang, L., Guo, X. N., Qi, X. G., \& Qian, H. F. (2011). Influence of the degree of hydrolysis (DH) on antioxidant properties and radicalscavenging activities of peanut peptides prepared from fermented peanut meal. European Food Research and Technology, 232(6), 941-950. http://dx.doi.org/10.1007/s00217011-1466-0. 